\title{
Aquatic systems in semi-arid Brazil: limnology and management
}

Ecossistemas aquáticos do semi-árido brasileiro: aspectos limnológicos e manejo

José Etham de Lucena Barbosa ${ }^{1}$, Elvio Sérgio Figueredo Medeiros ${ }^{2}$, Jandeson Brasil ${ }^{1}$,

Raquel da Silva Cordeiro ${ }^{3}$, Maria Cristina Basilio Crispim ${ }^{4}$ and

Gustavo Henrique Gonzaga da Silva

${ }^{1}$ Departamento de Biologia, Universidade Estadual da Paraíba - UEPB, Campus I, Rua Baraúnas, 351,

Bairro Universitário, CEP 58429-500, Campina Grande, PB, Brazil

e-mail: ethambarbosa@hotmail.com; jandesonbrasil@yahoo.com.br

${ }^{2}$ Departamento de Biologia, Universidade Estadual da Paraíba - UEPB, Campus V,

Rua Horácio Trajano de Oliveira, s/n, Cristo Redentor, CEP 58020-540, João Pessoa, PB, Brazil

e-mail: elviomedeiros@hotmail.com

${ }^{3}$ Programa de Pós-graduação em Ecologia e Conservação, Universidade Estadual da Paraíba - UEPB,

Campus I, Rua Baraúnas, 351, Bairro Universitário, CEP 58429-500, Campina Grande, PB, Brazil e-mail: raqquel.cordeiro@gmail.com

${ }^{4}$ Departamento de Sistemática e Ecologia, Centro de Ciências Exatas e da Natureza, Universidade Federal da Paraíba - UFPB, Cidade Universitária, Campus I,

CEP 58059-900, João Pessoa, PB, Brazil

e-mail: ccrispim@hotmail.com

${ }^{5}$ Laboratório de Limnologia e Qualidade de Água, Universidade Federal Rural do Semiárido - UFERSA, e-mail: gustavo@ufersa.edu.br

\begin{abstract}
Aquatic systems in semi-arid Brazil include natural shallow lakes, artificial reservoirs and intermittent streams and rivers. These systems are distinctive features in the semi-arid landscape and comprise a range of associated systems functioning as an ever-changing mosaic of dry/wet patches. Lakes and reservoirs in semi-arid Brazil are subject to important periods of water shortages, whereas rivers and streams are characterized as highly variable and driven by the extremes of water flow and its absence. Within this view a catchment-scale approach must be used to create a holistic model to conceptualize and comprehend these aquatic systems, since the aquatic environment types in the semi-arid region of Brazil incorporate broader aspects within the catchment scale such as geomorphology, vegetation, climate and land use. This paper summarizes some of the information on the aquatic systems of the Brazilian semi-arid region and shows the importance of limnological studies in this region. It also attempts to establish perspectives for future research considering the catchment as a scale for surveying biological processes and limnological characteristics of the various aquatic systems. It is presented information on their overall structure and functioning, as well as characteristics of some biological communities, such as phytoplankton, periphyton, aquatic macrophytes, benthic invertebrates and fish. The importance of the understanding of eutrophication in reservoirs and the role of the dry phase in streams is emphasized, and information on possible actions of planning and management to improve water quality of reservoirs are presented.
\end{abstract}

Keywords: arid and semi-arid zones, aquatic biodiversity, reservoirs and intermittent rivers.

Resumo: Os ecossistemas no semiárido brasileiro englobam lagos rasos naturais, reservatórios artificiais e rios e riachos intermitentes. Estes sistemas são particularidades na paisagem do semiárida e compreendem uma grande variedade de sistemas associados, funcionando como um mosaico em constante mudança entre épocas de seca e chuva. Lagos e reservatórios no semiárido brasileiro estáo sujeitos a importantes períodos de escassez de água, enquanto que os rios e riachos são caracterizados como altamente variáveis e impulsionados pelos extremos de fluxo de água e sua ausência. Dentro desta perspectiva uma abordagem em escala de bacia hidrográfica deve ser usada para se criar um modelo holístico para conceituar esses sistemas aquáticos, uma vez que os tipos de ambientes aquáticos na região semiárida do Brasil incorporam aspectos mais amplos dentro da escala de bacia hidrográfica como geomorfologia, clima, vegetação e uso da terra. Este artigo 
sintetiza algumas das informaçóes sobre os sistemas aquáticos da região semiárida brasileira e mostra a importância de estudos limnológicos nesta região. Ele também tenta estabelecer perspectivas para pesquisas futuras considerando a bacia hidrográfica como uma escala para levantamento de processos biológicos e as características limnológicas dos vários sistemas aquáticos. É apresentada informaçôes sobre sua estrutura e funcionamento geral, bem como características de algumas comunidades biológicas, tais como o fitoplâncton, perifíton, macrofitas aquáticas, invertebrados bentônicos e peixes. A importância do entendimento da eutrofização em reservatórios e o papel da fase de seca em riachos são enfatizados, e informaçóes sobre possíveis açóes de planejamento e gestão para melhorar a qualidade da água dos reservatórios são apresentados.

Palavras-chave: zonas áridas e semiáridas, biodiversidade aquática, reservatórios e rios intermitentes.

\section{Introduction}

Arid and semi-arid zones represent a third of the land cover of the planet, encompassing about 61 million $\mathrm{km}^{2}$ (Pimm, 2001; Leemans and Kleidon, 2002) and these areas are inhabited by a fifth of the world's human population (Galbally et al., 2010). Such areas have been subject to increased of human population, various models of land use, water body eutrophication, natural water flow management and climatic changes. These factors impose important challenges for the conservation of biodiversity, maintenance of habitat integrity, food production and availability of drinking water for in arid and semi-arid systems worldwide (Brasseur et al., 2003; Solomon et al., 2007).

In addition, it has been estimated that semiarid areas in the tropical region of the planet cover most of the developing countries, including Latin America, sub-Saharan Africa, India and southeastern Asia (Icrisat, 1998). Three great arid and semi-arid regions are represented in South America: the Guajira region, in northern Colombia and Venezuela; the dry diagonal of the southern cone, covering the Patagonia, Argentina, Chile and the Andes; and the semi-arid region of northeastern Brazil (Ab'Saber, 2003; Cavalcante and Salles, 2011).

Throughout the world the semi-arid regions are defined as transition zones between arid and subhumid regions, where precipitation is lower that evaporation and the temperatures are high during warmer months. The semi-arid region of Brazil is defined and delimited based on three criteria (Brasil, 2005): 1) average annual precipitation lower than $800 \mathrm{~mm}$; 2) aridity index below 0.5 , which is calculated as the hydric balance between precipitation and evapotranspiration for the period between 1961 and 1990; and 3) chance of drought greater than $60 \%$, based on the period between 1970 and 1990. Based on this classification, the
Brazilian semi-arid region encompasses an area of $969.589,4 \mathrm{~km}^{2}$, covering $11 \%$ of the country, and 1.132 municipalities and nine states (Piauí, Ceará, Rio Grande do Norte, Paraíba, Pernambuco, Alagoas, Sergipe, Bahia and Minas Gerais) (Figure 1).

Representing $70.6 \%$ of the northeastern region of Brazil, this semi-arid region is the most populated in the world. Furthermore, the Brazilian semi-arid possesses a range of climatic and geomorphologic characteristics that make this area distinct from other arid and semi-arid regions in the tropics. These characteristics are 1) high spatial and temporal variation in precipitation, 2) low thermal amplitude with temperatures above $25^{\circ} \mathrm{C}$ throughout the year, 3) high potential evapotranspiration, leading to a deficit in the hydric balance during at least nine months of the year, 4) shallow and poorly structured soils 5) drainage catchments characterized by intermittently flowing streams and rivers and 6) decidual vegetal cover, termed "Caatinga".

Therefore, the conservation value of aquatic systems and their management in semi-arid regions are enhanced due to the dry nature of the environment, whereas the importance of the linkages between the aquatic systems must also be recognized. This paper summarizes some of the information on the aquatic systems of the Brazilian semi-arid region and shows the importance of limnological studies in this region. It also attempts to establish perspectives for future research considering the catchment as a scale for surveying biological processes and limnological characteristics of the various aquatic systems.

\section{Management and Monitoring of Aquatic Systems at Catchment Scales}

The catchment-scale approach has been used as a more holistic model to conceptualize and 
comprehend aquatic systems, since aquatic environment types incorporate broader aspects within the catchment such as geomorphology, vegetation, climate and land use. These characteristics lead to the formation a mosaic of subsystems connected by biotic and abiotic processes (Smith and Petrere Junior, 2000; Schiavetti and Camargo, 2002; Brigante and Espíndola, 2003). The catchment basin also integrates structural and functional processes which in turn result from the interaction among geomorphology and social-economical issues across the drainage area. Therefore, in order to effectively understand and manage aquatic systems, the catchment area must be evaluated as a whole, being the ideal unit of study for identifying processes that sustain biodiversity at landscape levels, not only at local levels. This approach is desirable since the maintenance and/ or restoration of the aquatic systems incorporates a multiple-scale approach and given the history of human adaptation to the Brazilian semi-arid, the configurations of ecosystems and the social system should be taken into account in management and conservations plans for the catchment areas (Tundisi and Schiel, 2002; Tundisi, 2003; Maltchik and Medeiros, 2006).

Other important aspects that qualify the catchment area as the fundamental unit of study and management are: (i) the possibility of integrated solutions for local and regional development and solution of water and land conflicts (Tundisi and Matsumura-Tundisi, 1995); (ii) integration among decision makers, research institutions and land owners, to enhance sustainable development and (iii) development a data sets about the different aspects of the catchment (economic, social, morphological and biological) (Tundisi and Schiel, 2002; Tundisi, 2008). Furthermore, the study of river basins has been incorporating more theoretical frameworks such as the River Continuum Concept (Vannote et al., 1980); the Flood Pulse Concept (Junk et al., 1989); the Nutrient Spiraling (Newbold et al., 1982), as well as concepts associated with landscape ecology (Hansson et al., 1995; Thorp et al., 2006).

Within this view, a catchment area functions and interacts from a four-dimensional organization (Ward, 1989). Longitudinally, the interactions occur between processes up and down stream, including the tributaries and the main river channel, whereas laterally, processes and biota interact between the river and its floodplain. Vertically, the catchment presents important integration between surface and sub-surface waters, resulting from geological and morphological processes that affect the degree of interaction between the upwelling and downwelling waters. The fourth dimension represents the temporal scale of functioning of the aquatic systems, including the structure and dynamics of the aquatic fauna and flora and their responses to flow variations. Catchment areas and their river systems have been seen as a continuous longitudinal gradient (Vannote et al., 1980) or as discontinuous stretches where biotic communities respond to local aspects of the landscape and that local communities are segregated structurally and functionally across the drainage basin. The later has been emphasized in the Uniqueness within the River Discontinuum (Poole, 2002) which proposes that river catchments are unique systems, being organized structurally and functionally in the catchment basin scale. In this case, the catchment would be formed by patches segregated across the catchment reaches and the dynamic of patches along the system would characterize the catchment area. Within this model, tributary and dams contribute to the segregation in the system leading to a mosaic of patches and creating a meta-structure of functional sub-systems (Medeiros et al., 2008).

It is important to note that aquatic ecological systems are complex, being necessary to consider the level of longitudinal organization of the catchment and the application of landscape models as tools for understanding these systems (Bunn and Arthington, 2002). A holistic view on how aquatic systems function and on how they are structured is fundamental to enable effective management and mitigation of the anthropogenic effects on waterways and catchments. A fundamental tool in this understanding is the monitoring of key processes and organisms which generate sensitive and effective indicators of system alterations and their consequences on biotic interactions. This in turn will lead to effective strategies to the use, management and conservation of aquatic systems (Cottingham and Carpenter, 1998; Likens, 2001; Tundisi, 2008).

\section{Aquatic Systems in Semi-arid Brazil: Reservoirs and Intermittent Rivers}

Aquatic systems in semi-arid Brazil include natural shallow lakes (Maltchik et al., 1999), artificial reservoirs (Barbosa, 2002) and intermittent streams and rivers (except for the perennial São Francisco River and artificially regulated rivers) (Maltchik and Medeiros, 2006). These systems are 
distinctive features in the semi-arid landscape and comprise a range of associated systems functioning as an ever-changing mosaic of dry/wet patches.

Lakes and reservoirs in semi-arid Brazil are subject to important periods of water shortages. In this region, reservoirs present low outflow and high water residence time associated with a negative hydric balance and high temperatures during most of the hydrological cycle. This intensifies the accumulation and concentration of nutrients, making these systems considerably more vulnerable to eutrophication than reservoir in more humid areas. Eutrophication has been reported as a major issue leading to decrease in water quality (Bouvy et al., 2000; Costa et al., 2006; EskinaziSant'Anna et al., 2007). Furthermore, reservoirs receive heavy loads of nutrients, as a consequence of high susceptibility to soil erosion, inputs of sewage from urban areas and inadequate land use and occupation. The poor quality of the water accumulated in such reservoirs severely restricts its use and aggravates the already scarce sources of water for human consumption.

The climate in the Brazilian semi-arid region is characterized by a mean annual precipitation ranging from 400 to $800 \mathrm{~mm}$, with a rainy season usually occurring between January and July, but presenting wide spatial and temporal variation. In general, precipitation above $100 \mathrm{~mm}$ is reached only between February and May. The dry season (August to December) is marked by an almost complete lack of precipitation. The evaporation rate is estimated around 3 m.yr ${ }^{-1}$ (Bouvy et al., 1999).

The absence of precipitation during the dry period, and the continuous consumption of water throughout the year decrease continuously the water levels in man-made lakes from August to December. In dryer years some reservoirs can completely dry out. This strong reduction in the water level results in a series of modifications in the reservoir ecosystems, including salt and nutrient concentration (Bouvy et al., 1999). Due to the climatic conditions in the semi-arid region of Brazil, man-made lakes present long water residence time, being usually higher than one year (Bouvy et al., 1999; Eskinazi-Sant'Anna et al., 2007).

The man-made lakes from semi-arid Brazil are relatively shallow, with mean depth of aprox. $5 \mathrm{~m}$, and turbid, with Secchi depth usually lower than 1 m (Bouvy et al., 2000; Eskinazi-Sant'Anna et al., 2007; Sousa et al., 2008). Water temperature is always high, with values greater than $23.5^{\circ} \mathrm{C}$, being the lower values observed between June and
August. Due to the high water temperatures, diel stratifications can be formed in the water column (Bouvy et al., 1999; Dantas et al., 2008). Water pH values from reservoirs are usually above 8 , and they also present high alkalinity values (>2000 $\left.\mu \mathrm{Eq} . \mathrm{L}^{-1}\right)$, being the highest values observed usually in the dry season (Bouvy et al. 2000; Huszar et al., 2000; Eskinazi-Sant'Anna et al., 2007). These high pH and alkalinity values are related to high carbonate and bicarbonate concentrations naturally found in the aquatic ecosystems from the region, due the influence of soil type (Leprun, 1983). The manmade lakes present high electric conductivity values, usually greater than $300 \mu \mathrm{S} . \mathrm{cm}^{-1}$ (Bouvy et al., 2000; Eskinazi-Sant'Anna et al., 2007). In general, the variation in conductivity values is negatively correlated with water levels (Bouvy et al., 1999). At some occasions, such as droughts promoted by El Nińo events, the electric conductivity values can reach values greater than $10.000 \mu \mathrm{S} . \mathrm{cm}^{-1}$ (Bouvy et al., 2000). Oxygen concentrations are generally above $4 \mathrm{mg} . \mathrm{L}^{-1}$ (Bouvy et al., 2000), and sometimes can occur vertical variation, with values decreasing with depth, yet not reaching anoxic conditions (Eskinazi-Sant'Anna et al., 2007).

Most municipalities of semi-arid Brazil do not present wastewater treatment. Thus, the total nutrient concentration is, generally high, the mean values of total nitrogen concentration being greater than $2500 \mu \mathrm{g} . \mathrm{L}^{-1}$ and the total phosphorus higher than $100 \mu \mathrm{g} . \mathrm{L}^{-1}$, showing the high eutrophication levels in these aquatic ecosystems (Huszar et al., 2000; Eskinazi-Sant'Anna et al., 2007). Dissolved nutrient concentrations show high variability, but in general, they are relatively high. The mean concentration of reactive soluble phosphorus ranges between 15 and $37 \mu \mathrm{g} . \mathrm{L}^{-1}$, and dissolved inorganic nitrogen between 87 and $107 \mu \mathrm{g} . \mathrm{L}^{-1}$, with ammonium representing the larger contribution of nitrogen forms (Bouvy et al., 2000; Huszar et al.,2000).

Intermittent streams and rivers are distributed in most of the world's semi-arid lands. Although not restricted to dry regions, intermittent rivers are characteristic aquatic systems in semi-arid Brazil. These systems are increasingly growing in focus of scientific and applied research as drylands expand (Tooth, 2000). Recent research in dryland river systems of Brazil indicates that the hydrological disturbances are the driving forces structuring biotic communities and that the spatial heterogeneity resulting from disturbance plays a major role in organizing communities spatially (Maltchik and Florin, 2002; Medeiros et al., 2008). 
There are important reasons to study intermittent rivers in semi-arid Brazil. From a theoretical point of view the models that integrate biotic processes and function with form and geomorphology in dryland rivers are rare and general in nature, not being specific to intermittent systems. This occurs despite the fact that fluvial processes are significant agents of landscape erosion and deposition meaning that intermittent river systems can be active landforming agents (Thomas, 2011). Furthermore, concepts specific to dryland rivers deal with channel behavior focusing on landform dynamics, whereas models that integrate biological communities on the other hand have been developed for small perennial temperate streams or large tropical systems, and are hardly applicable to intermittent streams (eg. Vannote et al., 1980; Junk et al., 1989).

From an applied standpoint, general conceptual models and theories are a basic tool for the understanding of intermittent rivers and are needed if research is to be reverted and applied to catchment management and conservation of biotic processes at landscape scale (Bunn and Arthington, 2002). This is critical since many intermittent rivers and streams are under the threat or already being influenced by flow regulation schemes and other human activities. In Brazil, these practices have been altering the integrity of these systems by modification of the riparian vegetation, introduction of exotic species of plants and animals, change in fire regime, vegetation clearing, sand and ore extraction, and water pollution by pesticides, urban and industrial waste (Leal et al., 2005). Water storage associated with farming irrigation, also deplete the quality of the already scarce water resources and increase the threat of soil salinization in the semi-arid region of Brazil. In other dry regions, such modifications have been associated with changes in morphology of river channels and decline in average annual flows and peak discharges, as well as decrease in channel size and meander and parafluvial zone width (Everitt, 1993), with important consequences to biotic integrity and processes.

From a climatic viewpoint, semi-arid intermittent rivers and streams present rapid and strong correspondence to climatic changes and phenomena that occur in global scale (such as the El Niño-Southern Oscillation patterns), being accurate in forecasting of climatic patterns and acting as amplifiers global climatic changes (Molles and Dahm, 1990).

Intermittent streams are characterized by the extremes of flooding and drought. In arid and semi-arid lands, flooding is mostly associated with short flow events that vary in intensity, frequency and magnitude. In accordance to these criteria, Graf (1988) classified flooding in dry rivers as being seasonal, with multiple peaks, with a single peak and flash flooding. The type of flooding is the result of local and regional precipitation in a given hydrological cycle, flash flooding occurring in smaller river systems and seasonal flooding associated to larger basins. Droughts on the other hand, are longer events with specific phases also resulting from precipitation patterns. Typically, the period with no continuous surface water flow of an intermittent river can be separated into three phases. The "drying phase" occurs when continuous flow ceases, after the flooding period, and pools are formed in the river bed. During the "dry phase" (or dryness) there is no surface water. During the "rewetting phase", initial flow occurs with the onset of the flooding period (Stanley and Fisher, 1992).

Given the high spatial heterogeneity resulting from flooding and drought patterns and the temporal dynamics of water flow the aquatic fauna is subject to multiple scale processes. Two mechanisms have traditionally been proposed as capable of regulating biotic communities in such variable systems. Mechanisms involving deterministic processes incorporate the notion of equilibrium communities where diversity and composition of species are maintained avoiding competitive exclusion. Biotic interactions such as resource partitioning, predation and competition are major factors in this view. On the other hand, stochastic processes may also play an important role in biotic communities of intermittent streams. This is based in the idea that the physical habitat and chemical characteristics at local scales are rarely stable enough to allow communities to reach equilibrium. Therefore, community composition and diversity would be determined by species-specific responses to the unpredictable changes in the habitat rather than biotic interactions (Grossman et al., 1990). The dynamics between stochastic and deterministic mechanisms has been discussed and is yet to be established.

The recognition of intermittent streams as important sites of biodiversity and that their diversity is closely associated with natural patterns of flow and hydrological disturbances is, therefore, important for the conservation and management of these systems (Bunn and Arthington, 2002). This understanding will aid in the development of effective strategies for their conservation, otherwise 
regulation and alterations in flow regime will increase fragmentation and favor loss or substitution of biotic communities. Therefore, it is clear that, for intermittent streams, a multiple-scale approach is needed for the understanding of processes at a landscape level, and that the preservation of physical processes that create and maintain aquatic variability ensures that the aquatic biota is able to colonize these systems.

\section{Biological Communities and General Pattern}

\subsection{Phytoplankton community}

The man-made lakes from semi-arid Brazil present, in general, high chlorophyll concentrations (mean values higher than $20 \mu \mathrm{g} . \mathrm{L}^{-1}$ ), showing the eutrophic or hypertrophic conditions of those systems (Huszar et al., 2000; Barbosa et al., 2006; Eskinazi-Sant'Anna et al., 2007). The temporal pattern of phytoplankton biomass is determined by rain distribution throughout the year. According to Huszar et al. (2000) a temporal pattern comprises unimodal cycles with phytoplankton peaks occurring (i) during dry or wet periods; (ii) from the end of the dry period to the beginning of the rainy period; (iii) from the intermediate season until the rainy season, or even, (iv) during more than six months encompassing dry and rainy periods.

In general, Chlorophyceae is the most prominent group in terms of number of species. However, in terms of density, biomass and biovolume the phytoplankton community is usually dominated by Cyanobacteria, namely Cylindrospermopsis raciborskii (Woloszynska) Seenaya \& Subba Raju (Bouvy et al., 1999, 2000; Huszar et al., 2000; Barbosa and Mendes, 2004; Panosso et al. 2007; Dantas et al., 2010; Vasconcelos et al., 2011). Toxic cyanobacterial blooms are common in manmade lakes of semi-arid region of Brazil, frequently causing human health threats (Molica et al., 2005; Costa et al., 2006). As an example, a dramatic case of human poisoning by cyanotoxins took place in the northeast of Brazil resulting in the death of 76 patients submitted to haemodialysis that used water from a reservoir colonized by cyanobacteria (Carmichael et al., 2001). This event and other alike have been referred as the Caruaru syndrome.

Although cyanobacterial blooms in reservoirs of semi-arid Brazil are mainly related to the eutrophic conditions of these systems, other factors may also contribute to the success of cyanobacteria, such as environmental constancy, annual rain deficit and lack of water renewal, high temperatures and $\mathrm{pH}$, low N/P ratio, low ammonium concentration and absence of efficient predators (Bouvy et al., 1999, 2000; Huszar et al., 2000; Barbosa et al., 2010; Dantas et al., 2010).

\subsubsection{Periphytic algae}

The periphyton has been characterized as a complex array of microorganisms and organic detritus attached to natural or artificial substrates, which in turn may be dead or alive (Wetzel, 1983). Being predominantly composed by authotrophic algae, the periphyton plays an important role in the food web and exchange of matter between organic and inorganic components of the ecosystem (Lowe and Pan, 1996). Thus, the periphyton has the potential to influence the growth, development, survival and reproduction of organisms in aquatic systems (Campeau et al., 1994). Its potential as bioindicator for water quality and trophic status has been emphasized in many studies, mostly in small rivers and streams (Costa and Chellappa, 2000).

However, studies describing the periphytic communities in Brazil are recent, and so are the one developed in the semi-arid region of the country. This is most likely due to the lack of specialists in the subject in this region. In the state of Paraíba, the first attempts to study periphytic communities were made by Batalla and Watanabe (1993) surveying the Gramame and Mamuaba reservoirs. Despite that, the first published research from Paraíba on a refereed paper was the work from Maltchik et al. (1999), which described ecological aspects of periphytic algae in an intermittent stream.

At present, research on periphytic communities has been increasing as a result of investments of the Long-Term Ecological Program (PELD) in the Caatinga, which resulted in a book chapter (Dantas and Barbosa, 2005) comparing ficoperiphyton across different substrate types in lentic systems and six monographic works and a master's dissertation on the topic of periphytic algae.

\subsubsection{Aquatic macrophytes}

The overall dynamics of aquatic macrophytes is one of the most important aspects in their study. The basic patterns of spatial and temporal distribution of aquatic plants are explained by the physiological relations between plants and environmental conditions, as well as the tolerances and competitive abilities allowing growth at different levels of resource availability along environmental gradients. 
General patterns of distribution of the aquatic macrophytes are related with light and nutrient availability, temperature, $\mathrm{pH}$, alkalinity, salinity, discharge, water level, and geomorphology. Nevertheless, the biotic and abiotic variables interact to establish populational and individual patterns (Menendez and Peñuelas, 1993; Bini et al., 1999; Henry-Silva et al., 2010; Barendregt and Bio, 2003; Henry and Costa, 2003; Neiff and Poi de Neiff, 2003). It is noteworthy that aquatic plants are susceptible to different levels of chemical and physical disturbances that occur in catchment areas, such as dredging, mining, domestic and industrial waste pollution and alterations in water levels (Mackay et al., 2003; Thomaz et al., 2003; Ferreira et al., 2005; Pedro et al., 2006).

Forty species of aquatic macrophytes distributed across 22 families and 33 genera were observed for the Apodi/Mossoró (RN) river basin by HenrySilva et al. (2010). Poaceae and Cyperaceae were the richest taxa. The most frequent growth form were amphibian (42.5\%), with 17 species, emergent $(27,5 \%)$, free floating $(12,5 \%)$, submersed rooted $(10,0 \%)$ and floating leaved $(7,5 \%)$. The submersed rooted Hydrothrix gardneri and Ceratophyllum demersum were observed in great abundance and frequency in the Santa Cruz do Apodi reservoir, especially near net cages for tilapia (Oreochromis niloticus) growth. The free floating Eichhornia crassipes, Pistia stratiotes and Salvinia auriculata, commonly occurred in reaches crossing urban areas. It has been established that the richness of aquatic macrophytes is similar to that observed in other drainage basins across Brazil, and proposed that given the large number of reservoirs in semi-arid Brazil, the survey and monitoring of aquatic macrophytes is important, especially in the drainages that will receive waters from the São Francisco river transposition.

\subsubsection{Benthic invertebrates}

The first studies on benthic macroinverebrates in semi-arid Brazil, deal mostly with the taxonomy and distribution of specific taxa, such as Mollusca (Abílio et al., 2007). In reservoirs studies relate the biology and ecology of macroinvertebrates in the littoral sediment and associated with aquatic macrophytes (Abílio et al. 2005a, b, 2006; Abílio and Watanabe 1998, 2000, Brito-Junior et al. 2005, Souza and Abílio, 2006). It is important to mention that such studies frequently record the presence of the Planorbidae Biomphalaria straminea, the intermediate host for the human parasitic trematode Schistosoma mansoni.

The benthic macroinvertebrate fauna in Brazilian semi-arid streams is rich when compared with other dry systems, comprehending mostly insects, annelids and mollusks. Among the insects, Chironomidae is a very abundant taxa contributing with most of the individuals of the benthic fauna. Gomphidae, Libellulidae, Gerridae, Pleidae, Corixidae, Dytiscidae and Hydrophylidae are also common in Brazilian intermittent streams. Magnitude of flooding strongly influences the macroinvertebrate composition, by increasing the number of families after low-magnitude flooding and decreasing their numbers after floods of greater magnitude. Even though the resistance of benthic macroinvertebrates to higher-magnitude flooding is low, Chironomidae are highly persistent. Among the benthic macroinvertebrates, the insects have been reported as the first colonizers after flooding. These are mostly the aquatic adults capable of flight which emerged prior to flooding (Maltchik and Silva-Filho, 2000; Maltchik and Medeiros, 2006).

\subsubsection{Fish}

Diversity of fish species in Brazilian semiarid streams is greatly affected by the extremely variable flows (Maltchik and Medeiros, 2001). These hydrological disturbances create a range of habitats that enable coexistence of species and are likely to reduce exclusion by competition. Studies indicate that diversity, food resources and reproductive activity are partitioned among species across temporal and spatial scales. Furthermore, the spatial heterogeneity created by different hydrological phases, and the environmental variations within these phases are important factors in the maintenance of a rich and variable fish community, while decreasing prolonged dominance of species. The dry periods lead to the formation of pools in the river bed with different sizes and degrees of permanence. Such habitats enhance the resilience of fish after flooding, since many species use them as reproductive sites (Medeiros and Maltchik, 2001). The larger temporary and semi-permanent pools act as safe habitats and reduce mortality associated with flood and drought disturbance. Fish populations at these habitats probably function as metapopulations enabling persistence of fish across stream reaches and other bodies of water by dispersal migration when the wet phase commences.

This natural dynamics has been threatened by the expansion of water resource development in 
semi-arid Brazil. Increasing pressure for drinking and irrigation water has led to water resource development policies which emphasize construction of large dams, barrages, artificial channels and, more recently, large-scale inter-basin water transfers. Efforts to manage flow appropriately to allow water storage and biotic integrity are virtually inexistent and/or hampered by limited scientific information on the ecological processes driving stream flora and fauna. Human occupation in this region and the strategies adopted for land use and forest management has led to changes in local climate and the intensification of arid conditions (Leal et al., 2005). Furthermore, long-term programmes of introduction of exotic species of fish contribute to the deterioration of the natural biodiversity .

Conservation values of aquatic systems in drylands are enhanced given the dry nature of the surrounding environment (Williams, 1999). Brazilian semi-arid streams provide a range of services, from socio-economic to ecological. The most important issues in the conservation of these streams are their recognition as providers of such services. Failure to recognize the importance of the ecological processes and the link between natural hydrological disturbances and biodiversity, will lead to the extinction of species and the loss or disruption of natural patterns diversity and species distribution. To be effective, conservation and management efforts in semi-arid streams of Brazil will need to understand and maintain key ecosystem processes and their drivers (e.g. hydrological disturbance, river-riparian zone interactions), as well as dispersal pathways and their associated refugia. These agents have been pointed as the most important aspects that enable resilience of the aquatic fauna and maintain their biodiversity and processes (Maltchik and Medeiros, 2006).

\section{Using Limnological Knowledge in Environmental Planning and Managing: a Study Case for Reservoirs in the Semi-arid Region of Brazil}

Man-made reservoirs in semi-arid Brazil present important limnological characteristics. These systems are prone to have their trophic status increased to eutrophic or hypereutrophic during dry periods, resulting from high evaporation and concentration of nutrients (Crispim et al., 2000; Barbosa, 2002). This is aggravated by their small size and depths leading to long water retention time.

The Long-Term Monitoring Program (PELD/ Caatinga) has been monitoring several reservoirs in semi-arid Brazil, in order to understand their structure and functioning. The monitoring of the Taperoá II reservoir has shown that the water quality has improved throughout the study period. Observation of the precipitation chart (Figure 2) reveals an increase in rainfall since 2004, causing more frequent spill outs and decreasing the water retention in the reservoir. This has led to the regression of the trophic status during the dry periods. An important response to this process has been observed to zooplankton, which decreased their peaks of maximum densities.

It has been observed in the Taperoá II reservoir high densities of Moina minuta (Cladocera, Crustacea) in the beginning of the wet period. During this phase this species dominates the water column, but shortly after it decreases in numbers leaving ephippia in the sediment (Crispim et al., 2003). This species is known to require large amounts of food (phytoplankton) and its densities can reach greater values in eutrophic waters (Vieira, 2007; Medeiros et al., in preparation). At the beginning of the rainy period algae densities are lower but their growth is rapid (Barbosa, 2002), providing food in significant quantities. The analysis of the effect of $M$. minuta on algal growth and the comparison with the foraging rates of the calanoid copepod Notodiaptomus cearensis and the rotifer Brachionus urceolaris showed that M. minuta presents higher feeding rates (twice as much compared with $N$. cearensis and ten times the rates of $B$. urceolaris), regardless of the amount of food provided. Nevertheless, B. urceolaris showed greater foraging in the presence of greater amounts of food, whereas $N$. cearensis showed greater foraging in the presence of lower food amounts. These results show that, the quality of the food available not being considered, some species of zooplankton may have their foraging rates inhibited depending on the amount of food available in the water. This explains, at least in part, the segregation in species composition among reservoirs with different levels of eutrophication.

Therefore, the rapid decrease in densities of M. minuta after its peak can be explained by the consumption of food at rates too high, leading to densities of prey items too low to sustain the entire populations of this cladoceran. Furthermore, this is reflected in the water transparency, which is greater soon after the blooms of $M$. minuta, characterizing a period of clearer waters, the clear water phase (Figure 3). 


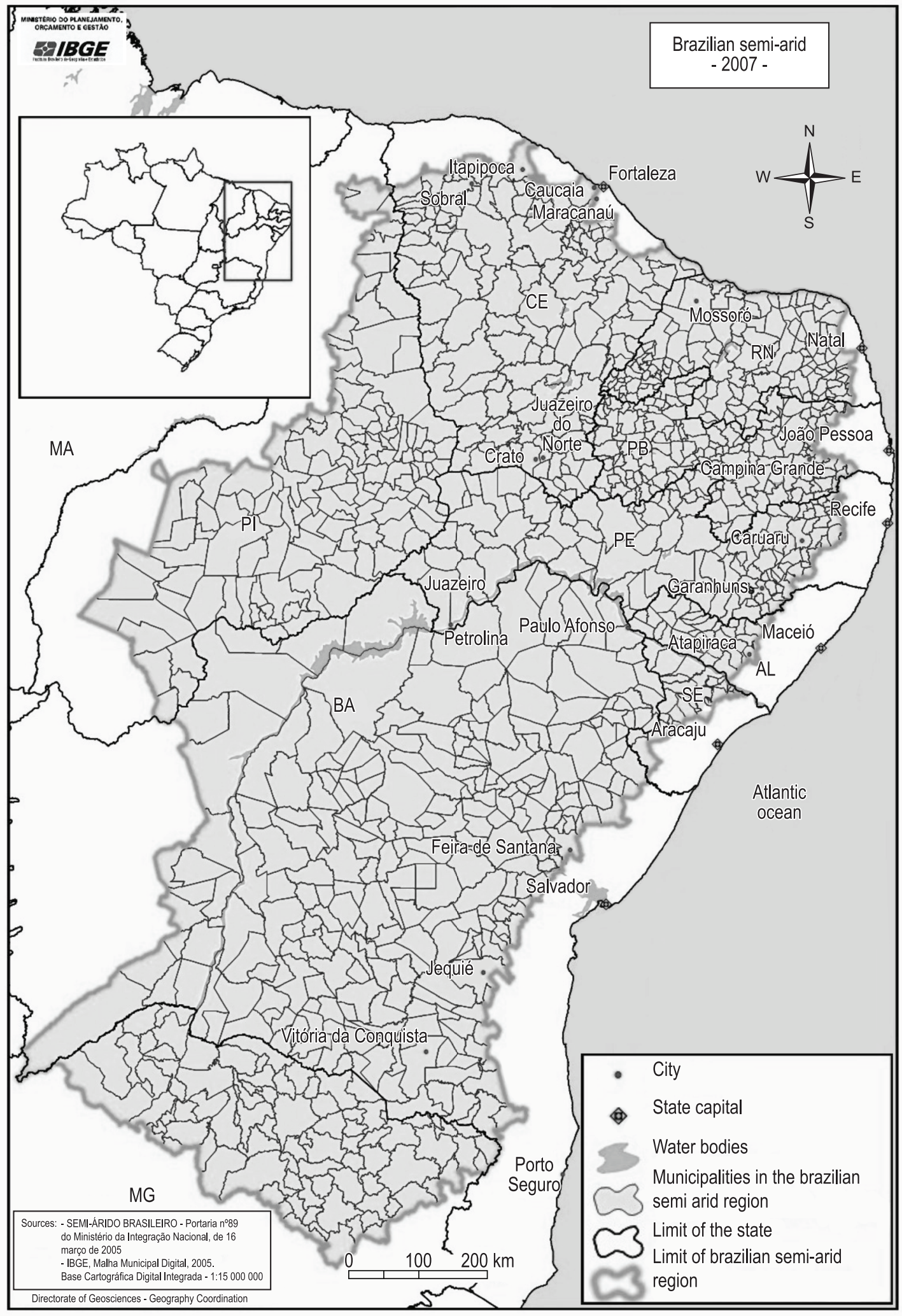

Figure 1. Delimitation of Brazilian semi-arid (source: Brasil, 2005).

Associated with the better water quality, after the effect of the presence of $M$. minuta in the water column, it was observed the increase in the abundance of other species such as the Cladocera Ceriodaphnia cornuta and Diaphanosoma spinulosum and the Calanoid Copepod N. cearensis. However, 

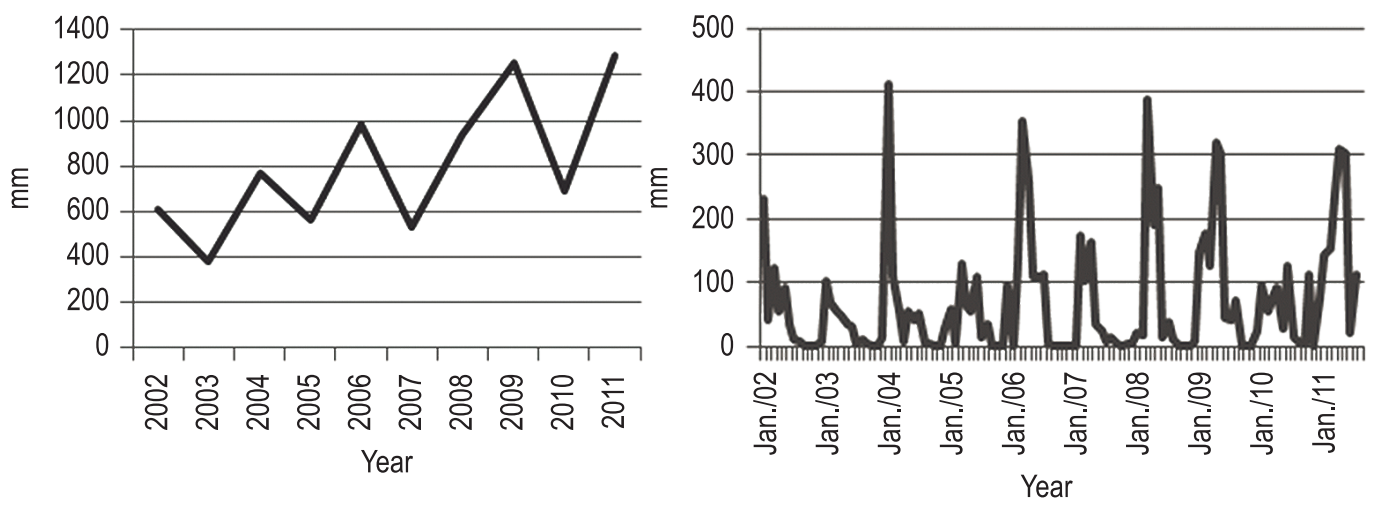

Figure 2. Annual and monthly cumulative precipitation in the Taperoá municipality (semi-arid Brazil) from 2002 to 2011 .
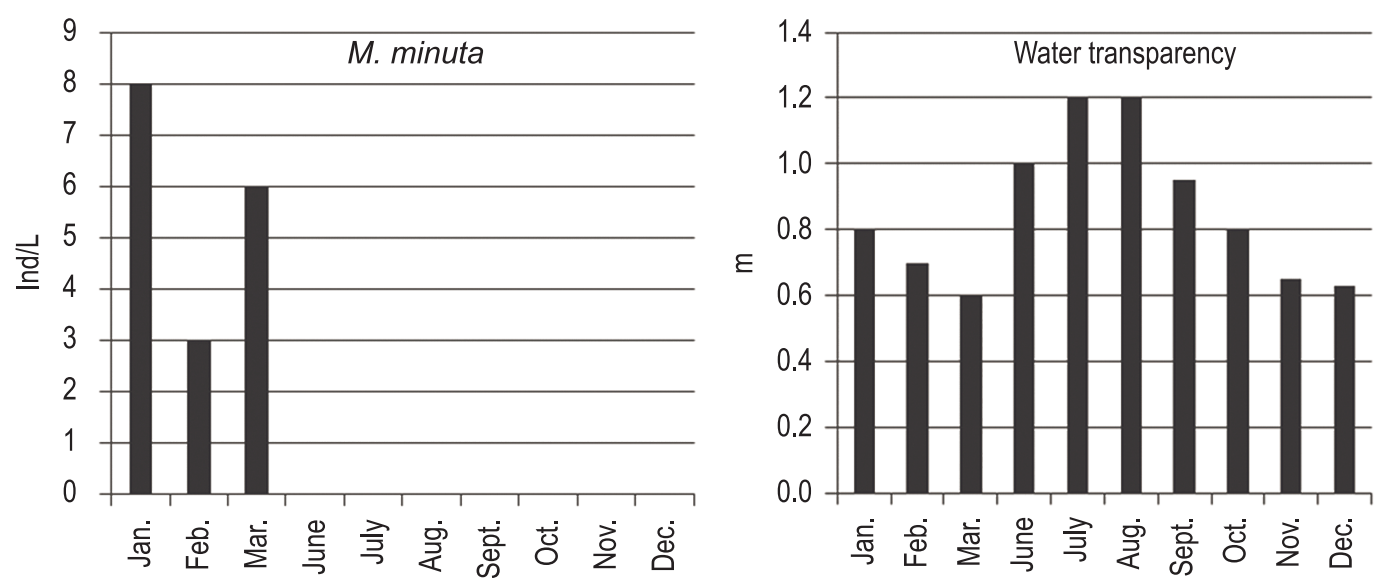

Figure 3. Densities of $M$. minuta and the water transparency in the Taperoá II reservoir.

these species are not able to control the algal growth as effectively as $M$. minuta and are eventually replaced by the Rotifera which starts to appear in greater richness as the Ciclopoid Copepod. M. minuta can, therefore, be seen as a key species in such reservoirs, enabling the presence of others that succeed it. From a management point of view, the presence of this species can help increase the quality of the water (at least regarding transparency and microalgae growth) in reservoirs in semi-arid Brazil by controlling the density of the phytoplankton. Interestingly, $M$. minuta has been observed again in the end of the dry period when the water is getting eutrophic again, but it does not show the same levels of density observed in the beginning of the hydrological cycle. This indicates that food may not be appropriate at this period or some other factor may be affecting the densities of the species.

Crispim et al. (2009) observed that the presence of a biofilm in the substrate enhances the removal of phosphates and nitrogen from the water, this biofilm being more efficient than the absorption made by aquatic macrophytes such as the Eichornnia crassipes. The latter was in turn more effective in the removal of nitrogen than phosphorus. Nevertheless, associated with the presence of phyto- and zooplankton, the macrophyte cover is essential to the maintenance of larger predators like fish and their eggs. For instance, Montenegro et al., (in preparation) observed in the Taperoá II reservoir that the ichthyoplankton was more associated with macrophyte stands than with other areas of the reservoir.

On the other hand, exotic species of fish, such as the Oreochromis niloticus has playing a negative role in these systems since it competes with native species (Figueredo and Giani, 2005) and constructs nests in deeper areas of the reservoirs releasing nutrients to the water. Furthermore, studies in reservoirs show this species as a planktivore (Montenegro, 2007) that can control zooplankton populations and enable the growth of phytoplankton, contribution to water turbidity and eutrophication. This species 
has been introduced to increase fishing and food availability to human populations, but this has not been effective since Oreochromis niloticus does not reach larger sizes in eutrophic environments.

With this limnological knowledge the management and planning for resource use in semi-arid Brazil, reservoirs must take into account the effects of biotic factors in their water quality. Since the richness of fish has been associated with the water quality of the reservoirs it is important that the conditions that promote fish richness and water quality are maintained. Also, incentives to remove exotic species and prevention of their introduction should be considered by decision makers and managers. Associated with that, is the fact that some species of Cladocera reach greater sizes (and higher reproductive rates) in the presence of invertebrate predators and the opposite in the presence of vertebrate predators (Crispim, 1998). Thus, in lower densities of vertebrate visual predators, invertebrate predators (Copepoda Ciclopoida or insect larvae) can contribute to the control of phytoplankton by allowing greater sizes and reproductive rates of cladocerans.

Furthermore, the maintenance of macrophyte stands, and their management, may increase water quality, by removal of nutrients and increase in richness of fish and invertebrate species, such as Cladocera, Rotifera, Copepoda, Molusca and Insecta. The importance of macrophyte stands also includes their use as foraging and shelter for eggs and young individuals.

The presence of substrata that allow the establishment of a biofilm is an important element in the reduction of nutrients in the water. The use of artificial substrata for the establishment of this biofilm is important. Given that, the biofilm represents food for consumers, the nutrients removed from the water would be transferred to fish and invertebrates increasing their biomass and sustaining larger and more diverse communities. This biofilm requires less management than macrophytes, for instance, that need to be removed when in large quantities. Such approach would also be important in cases where fish are being farmed in enclosures, since the nutrients produced by farming can be absorbed or removed by bioremediation.

An important characteristic of Brazilian semiarid reservoirs is that they dry out after long dry periods. In such cases, the removal of the excess sediment in the bottom of these dry reservoirs should be preferred as opposed to dredging, when there is still water available. This nutrient rich sediments removed could be used as fertilizer by local farmers and at the same time preventing these nutrients to be released in the water.

Therefore, eutrophication in Brazilian semi-arid reservoirs can be mitigated by taking relatively simple actions, associated with the control of nutrient inputs through the drainage basin and management of local biotic processes in order to increase the quality of the water in these systems.

\section{Final Considerations}

Increased in human population growth in semi-arid Brazil and the associated expansion of water resource development may be regarded as the major threats to ecosystem integrity and loss of biodiversity. Eutrophication and pollution are important factors affecting biodiversity in reservoirs, whereas promotion of lenthic conditions by construction of dams and large-scale interbasin water transfers are important threats to the intermittent stream biodiversity. Associated to that numerous human activities threaten the biotic integrity and biodiversity in aquatic systems of semi-arid Brazil such as sand and ore extraction and land-use practices that alter the riparian vegetation of water bodies, introduction of exotic species of plants and animals and vegetation clearing.

In northeastern Brazil these threats are enhanced by the dry nature of the environment and the recurrent droughts (Tundisi, 2003). These factors, coupled with the current patterns of global climate change are very likely to intensify the semi-arid conditions and caused further loss of diversity. Therefore, effective conservation and management efforts in semi-arid Brazil need to start by generating knowledge on the processes that maintain ecosystem diversity at catchment scale and on the importance of pathways for organisms and diversity and their associated refugia.

\section{References}

AB'SABER, A. 2003. Os dominios da natureza no Brasil: potencialidades paisagísticas. Cotia: Ateliê.160 p. http://dx.doi.org/10.1590/S003646652003000100016

ABÍLIO, FJP., FONSECA-GESSNER, AA., WATANABE, T. and LEITE, RL. 2005a. Chironomus gr. decorus (Diptera: Chiromonidae) e outros insetos aquáticos de um açude temporário do semi-árido paraibano, Brasil. Entomologia y Vectores, vol. 12, no. 2, p. 233-242. http://dx.doi.org/10.1590/S032803812005000200007

ABÍLIO, FJP., FONSECA-GESSNER, AA., WATANABE, T. and LEITE, RL. 2005b. Fauna de 
Chironomidae e outros insetos aquáticos de açudes do semi-árido paraibano, Brasil. Entomologia y Vectores, vol.12, no. 2, p. 255-264. http://dx.doi.org/10.1590/ S0328-03812005000200009

ABÍLIO, FJP., FONSECA-GESSNER, AA., LEITE, RM. and RUFFO, TLM. 2006. Gastrópodes e outros invertebrados bentônicos do sedimento e associado a Eichhornia crassipes de um açude hipertrófico do semi-árido paraibano. Revista de Biologia e Ciências da Terra, vol. 6, no. 1, p.165-178.

ABÍlO, FJP., RUFFO, TLM., SOUZA, AHFF, FLORENTINO, HS., OLIVEIRA JUNIOR, ET., MEIRELES, BN. and SANTANA, ACD. 2007. Macroinvertebrados bentônicos como bioindicadores de qualidade ambiental de corpos aquáticos da Caatinga. Oecologia Brasiliensis, vol.11, no. 3, p. 397-409.

ABÍLIO, FJP. and WATANABE, T. 1998. Ocorrência de Lymnaea columella Say, 1817 (Gastropoda: Lymnaeidae), hospedeiro intermediário da Fasciola hepatica, para o Estado da Paraíba, Brasil. Revista de Saúde Pública, vol. 32, no. 2, p.185-186. http:// dx.doi.org/10.1590/S0034-89101998000200013

ABÍLIO, FJP. and WATANABE, T. 2000. Moluscos de ecossistemas dulceaqüicolas das regióes favorecidas pela transposição das águas do Rio São Francisco. In Anais do V Simpósio de Ecossistemas Brasileiros: Conservação, 2000. São Paulo: ACIESP. p. 170-175.

BARBOSA, JEL. 2002. Dinâmica do fitoplâncton $e$ condicionantes limnológicos nas escalas de tempo (nictemeral/sazonal) e de espaço (horizontal/vertical) no Açude Taperoá II: trópico semi-árido nordestino. São Carlos: Universidade Federal da São Carlos. [Tese de doutorado].

BARBOSA, JEL. and MENDES, JS. 2004. Estrutura da comunidade fitoplanctônica e aspectos físicos e químicos das águas do reservatório Acauã, semiárido paraibano. In Anais do X Reunião da Sociedade Brasileira de Ficologia, 2004. Salvador. p. 339-360.

BARBOSA, JEL., BRASIL, J., MONTINEGRO, AKM., FRANÇA, JC. DE and OLIVEIRA, FM. 2010. Variação Interanual do Fitoplâncton e Variáveis Limnológicas em um Açude Raso, Típico do SemiÁrido Brasileiro (Açude Taperoá II, Paraíba). In MOURA, AN., ARAÚJO, EL., BITTENCOURTOLIVEIRA, MC., PIMENTEL, RMM. and ALBUQUERQUE, UP., orgs. Reservatórios do Nordeste do Brasil: Biodiversidade, Ecologia e Manejo. Recife: NUPEEA Núcleo de Publicações em Ecologia e Etnobotânica Aplicada. vol. 1, p. 81-114.

BARBOSA, JEL., ANDRADE, RS., LINS, RP. and DINIZ, CR. 2006. Diagnóstico do estado trófico e aspectos limnológicos de sistemas aquáticos da bacia hidrográfica do rio Taperoá, trópico semi-árido brasileiro. Revista de Biologia e Ciências da Terra, no. 1, p. 80-89. Suplemento especial.
BARENDREGT, A. and BIO, AMF. 2003, Relevant variables to predict macrophytes communities in running waters. Ecological Modelling, vol. 160, p. 205-217. http://dx.doi.org/10.1016/S03043800(02)00254-5

BATALLA, JF. and WATANABE, T. 1993. Importância das algas perifíticas e bentônicas para o gastrópode Pomacea lineata (Spix, 1827) nas represas de Gramame e Mamuaba - Alhandra, Paraíba. In Resumos do $5^{\circ}$ Congresso Nordestino de Ecologia, 1993. Natal: Sociedade Nordestina de Ecologia, 1993. vol. 1, 195 p.

BINI, LM., THOMAZ, SM., MURPHY, KJ. and CAMARGO, AFM. 1999. Aquatic macrophyte distribution in relation to water and sediment conditions in the Itaipú Reservoir, Brazil. Hydrobiologia, vol. 415, p. 147-154. http://dx.doi. org/10.1023/A:1003856629837

BOUVY, M., FALCÃO, D., MARINHO, M., PAGANO, M. and MOURA, A. 2000. Occurrence of Cylindrospermopsis (Cyanobacteria) in 39 Brazilian tropical reservoirs during 1998 drought. Aquatic Microbial Ecology, vol. 23, p. 13-27. http:// dx.doi.org/10.3354/ame023013

BOUVY, M., MOLICA, R., OLIVEIRA, SD., MARINHO, M. and BECKER, B. 1999. Dynamics of a toxic cyanobacterial bloom Cylindrospermopsis raciborskii in a shallow reservoir in the semi-arid northeast Brazil. Aquatic Microbial Ecology, vol. 20, p. 285-297. http://dx.doi.org/10.3354/ame020285

Brasil. Ministério da Integração. 2005. Nova delimitação do semi-árido. Brasília.

BRASSEUR, GP., PRINN, RG. and PSZENNY, AAP., eds. 2003. Atmospheric chemistry in a changing world. Berlin: Springer. 300 p. http://dx.doi.org/10.5194/ acpd-3-4701-2003

BRIGANTE, J. and ESPÍNDOLA, ELG. 2003. Limnologia fluvial: um estudo no rio Mogi-Guaçu. São Carlos: Rima. 278 p.

BRITO-JUNIOR, L., ABÍLIO, FJP. and WATANABE, T. 2005. Insetos aquáticos do açude São José dos Cordeiros (semiárido paraibano) com ênfase em Chironomidae. Entomologia y Vectores, vol. 12, no. 2, p. 1-9. http://dx.doi.org/10.1590/S032803812005000200002

BUNN, SE. and ARTHINGTON, AH. 2002. Basic principles and ecological consequences of altered flow regimes for aquatic biodiversity. Environmental Management, vol. 30, no. 4, p. 492-507. http:// dx.doi.org/10.1007/s00267-002-2737-0

CAMPEAU, S., MURKIN, HR. and TIIMAN, RD. 1994. Relative importance of algae and emergent plant litter to freshwater marsh invertebrates. Canadian Journal of Fisheries and Aquatic Sciences, vol. 51, no. 3, p. 681-692. http://dx.doi.org/10.1139/ f9 $4-068$ 
CARMICHAEL, WW., AZEVEDO, SMFO., AN, JS., MOLICA, RJR., JOCHIMSEN, EM., LAU, S., RINEHART, KI., SHAW, GR. and EAGLESHAM, GK. 2001. Human fatalities from cyanobacteria: chemical and biological evidence for cyanotoxins. Environmental Health Perspectives, vol. 109, p. 663668. http://dx.doi.org/10.1289/ehp.01109663

CAVALCANTE, AMB. and SALLES, PA. 2011. Artificial islands in the Brazilian semiarid region. International Journal of Ecology and Environmental Sciences, vol. 37, no. 1, p. 75-79.

COSTA, IAS., AZEVEDO, SMFO., SENNA, PAC., BERNARDO, RR., COSTA, SM. and CHELLAPPA, NT. 2006. Occurrence of toxinproducing cyanobacteria blooms in a Brazilian Semi-arid reservoir. Brazilian Journal of Biology, vol. 66, no. 1b, p. 29-41. http://dx.doi.org/10.1590/ S1519-69842006000200005

COSTA, IAS. and CHELLAPPA, NT. 2000. Microalgas perifíticas da Barragem Armando Ribeiro Gonçalves, ASSU/RN. Revista de Ecologia Aquática Tropical, vol. 10, p. 85-93.

COTTINGHAM, KL. and CARPENTER, SR. 1998. Population, community, and ecosystem variates as ecological indicators: phytoplankton responses to whole-lake enrichment. Ecological Applications, vol. 8, no. 2, p. 508-530. http://dx.doi.org/10.1890/10510761(1998)008[0508:PCAEVA]2.0.CO;2

CRISPIM, MC. 1998. Estudo do impacto do esvaziamento da albufeira do Maranhão sobre a comunidade zooplanctônica-principais relaçóes bióticas que afetam os cladóceros. Lisboa: Faculdade de Ciências da Universidade de Lisboa. 183 p. [Tese de doutorado].

CRISPIM, MC., LEITE, RL. and WATANABE, T. 2000. Evolução do estado trófico em açudes temporários, no nordeste semi-árido, durante um ciclo hidrológico, com ênfase na comunidade zooplanctônica. In Anais do V Simpósio de Ecossistemas brasileiros: Conservação, 2000. Vitória. vol. 3, p. 422-430.

CRISPIM, MC., PAZ, RJ. and WATANABE, T. 2003. Comparison of different Moina minuta population dynamics ecloded from resting eggs in a semi-arid region in Brazil. Brazilian Journal of Ecology, vol. 1-2, p. 33-38.

CRISPIM, MC., VIEIRA, ACB., COELHO, SFM. and MEDEIROS, AMA. 2009. Nutrient uptake efficiency by macrophyte and biofilm: practical strategies for small-scale fish farming. Acta Limnologica Brasiliensia, vol. 21 , no. 4, p. 387-391.

DANTAS, EW. and BARBOSA, JEL. 2005. Comparação qualitativa da comunidade de algas perifíticas do epifíton, epilíton e epizoon em três ambientes lênticos da bacia do rio Taperoá, Paraíba. In Sociedade Brasileira de Ficologia, org. Formação de Ficólogos: um compromisso com a sustentabilidade dos recursos aquáticos. Rio de Janeiro: Museu Nacional. vol. 10, p. 399-410.
DANTAS, EW., BITTENCOURT-OLIVEIRA, MC. and MOURA, AN. 2010. Spatial-temporal variation in coiled and straight morphotypes of Cylindrospermopsis raciborskii (Wolsz) Seenayya et Subba Raju (Cyanobacteria). Acta Botanica Brasílica, vol. 24, p. 585-591. http://dx.doi.org/10.1590/ S0102-33062010000200028

DANTAS, EW., MOURA, AN., BITTENCOURTOLIVEIRA, MC., ARRUDA NETO, JDT. and CAVALCANTI, ADC. 2008. Temporal variation of the phytoplankton community at short sampling intervals in the Mundau reservoir, Northeastern Brazil. Acta Botanica Brasilica, vol. 22, p. 970-982. http:// dx.doi.org/10.1590/S0102-33062008000400008

ESKINAZI-SANT'ANNA, EM., MENEZES, R., COSTA, IAS., PANOSSO, R., ARAÚJO, MFF. and ATTAYDE, JL. 2007. Composição da comunidade zooplanctônica em reservatórios eutróficos do semi-árido do Rio Grande do Norte. Oecologia Brasiliensis, vol. 11, no. 3, p. 345-356. http://dx.doi. org/10.4257/oeco.2007.1103.10

EVERITT, BL. 1993. Channel responses to declining flow on the Rio Grande between Ft. Quitman and Presidio, Texas. Geomorphology, vol. 6, no. 3, p. 225-242. http://dx.doi.org/10.1016/0169555X(93)90048-7

FERREIRA, FC., SOUZA, UP. and PETRERE JUNIOR, M. 2005. Zonaçáo longitudinal da ictiofauna em ambientes lóticos. Boletim da Sociedade Brasileira de Limnologia, vol. 38, no. 1, p. 1-17.

FIGUEREDO, CC. and GIANI, A. 2005. Ecological interactions between Nile tilapia (Oreochromis niloticus, L.) and the phytoplanktonic community of the Furnas Reservoir (Brazil). Freshwater Biology, vol. 50, p.1391-1403. http://dx.doi.org/10.1111/ j.1365-2427.2005.01407.x

GALBALLY, I., MEYER, CP., WANG, YP. and KIRSTINE, W. 2010. Soil-atmosphere exchange of $\mathrm{CH} 4, \mathrm{CO}, \mathrm{N} 2 \mathrm{O}$ and $\mathrm{NOx}$ and the effects of land-use change in the semiarid Mallee system in Southeastern Australia. Global Change Biology, vol. 16, no. 9, p. 2407-2419. http://dx.doi.org/10.1111/j.13652486.2010.02161.x

GRAF, WL. 1988. Fluvial process in dryland rivers. New York: Springer-Verlag. 346 p.

GROSSMAN, GD., DOWD, JF. and CRAWFORD, M. 1990. Assemblage stability in stream fishes: a review. Environmental Management, vol. 14, no. 5, p. 661-671. http://dx.doi.org/10.1007/BF02394716

HANSSON, L., FAHRIG, L. and MERRIAN, G. 1995. Mosaic Landscape and Ecological Processes: Le Studies in Landscape Ecology 2. London: Chapman \& Hall. 356 p.

HENRY, R. and COSTA, MLR. 2003. As macrófitas como fator de heterogeneidade espacial: um estudo em três lagoas com diferentes conectividades com o 
rio Paranapanema. In THOMAZ, SM. and BINI, LM., eds. Ecologia e Manejo de Macrófitas Aquáticas. Maringá: Eduem. 460 p.

HENRY-SILVA, GG., MOURA, RST. and DANTAS, LLO. 2010. Richness and distribution of aquatic macrophytes in Brazilian semi-arid aquatic ecosystems. Acta Limnologica Brasiliensia, vol. 22, no. 2, p. 147-156. http://dx.doi.org/10.4322/ actalb.02202004

HUSZAR, VLM., SILVA, LHS., MARINHO, M., DOMINGOS, P. and ANNA, CLS. 2000. Cyanoprokaryote assemblages in eight productive tropical Brazilian waters. Hydrobiologia, vol. 424, p. $67-$ 77. http://dx.doi.org/10.1023/A:1003996710416

International Crops Research Institute for the SemiArid Tropics - ICRISAT. 1998. ICRISAT Policy and Strategy for Technology Exchange. Approved by the Governing Board. p. 25-26. Available from: http://www.syngentafoundation.org/index. cfm?pageID $=46$.

JUNK, WJ., BAYLEY, PB. and SPARKS, RE. 1989. The flood pulse concept in river - floodplain systems. In Proceedings of the International Large River Symposium, 1989. Canadian Special Publications of Fisheries and Aquatic Sciences. vol. 106, p. 110-127.

LEAL, IR., SILVA, JMC., TABARELLI, M. and LACHER, TE. 2005, Changing the course of biodiversity conservation in the Caatinga of northeastern Brazil. Conservation Biology, vol. 19, no. 3, p. 701-706. http://dx.doi.org/10.1111/j.15231739.2005.00703.x

LEEMANS, R. and KLEIDON, A. 2002. Regional and global assessment of the dimensions of desertification. In REYNOLDS, JF. and SMITH, DMS., eds. Global desertification: do humans cause deserts. Berlim: Dahlem University Press. p. 215-231.

LEPRUN, P. 1983. Primeira avaliação das águas superficiais do nordeste. Recife: SUDENE. 141 p. Relatório final de convênio.

LIKENS, GE. 2001. Biogeochemistry, the watershed approach: some uses and limitations. Marine and Freshwater Research, vol. 52, no. 1, p. 5-12. http:// dx.doi.org/10.1071/MF99188

LOWE, RL. and PAN, Y. 1996. Benthic algal communities as biological monitors. In STEVENSON, RJ., BOTHWELL, ML. and LOWE, RL., eds. Algal Ecology: Freshwater Benthic Ecosystems. New York: Academic Press. p. 31-56. http://dx.doi.org/10.1016/ B978-012668450-6/50051-5

MACKAY, SJ., ARTHINGTON, AH., KENNARD, MJ. and PUSEY, BJ. 2003. Spatial variation in the distribution and abundance of submersed macrophytes in an Australian subtropical river. Aquatic Botany, vol. 77, p. 169-186. http://dx.doi. org/10.1016/S0304-3770(03)00103-7
MALTCHIK, L., DUARTE, MDC. and BARRETO, AP. 1999. Resistance and resilience of periphyton to disturbance by flash floods in a Brazilian semiarid ephemeral stream (Riacho Serra Branca, NE, Brazil). In Anais da Academia Brasileira de Ciências, 1999. Rio de Janeiro: Academia Brasileira de Ciências. p. 791-800.

MALTCHIK, L. and FLORIN, M. 2002. Perspectives of hydrological disturbance as the driving force of Brazilian semiarid stream ecosystems. Acta Limnologica Brasiliensia, vol. 14, no. 3, p. 35-41.

MALTCHIK, L. and MEDEIROS, ESF. 2001. Does hydrological stability influence biodiversity and community stability? A theoretical model for lotic ecosystems from the Brazilian semiarid region. Ciência e Cultura. Journal of the Brazilian Association for the Advancement of Science, vol. 53, p. 44-48.

MALTCHIK, L. and MEDEIROS, ESF. 2006. Conservation importance of semi-arid streams in north-eastern Brazil: implications of hydrological disturbance and species diversity. Aquatic Conservation: Marine and Freshwater Ecosystems, vol. 16, no. 7, p. 665-677. http://dx.doi.org/10.1002/aqc.805

MALTCHIK, L. and SILVA-FILHO, MI. 2000. Resistance and resilience of the macroinvertebrate communities to disturbance by flood and drought in a Brazilian semiarid ephemeral stream. Acta Biologica Leopoldensia, vol. 22, no. 2, p. 171-184.

MEDEIROS, ESF. and MALTCHIK, L. 2001. Fish assemblage stability in an intermittently flowing stream from the Brazilian semiarid region. Austral Ecology, vol. 26, no. 2, p. 156-164. http://dx.doi. org/10.1046/j.1442-9993.2001.01099.x

MEDEIROS, ESF., SILVA, MJ. and RAMOS, RTC. 2008. Application of catchment- and localscale variables for aquatic habitat characterization and assessment in the Brazilian semi-arid region. Neotropical Biology and Conservation, vol. 3, no. 1, p. 13-20.

MENENDEZ, M. and PEÑUELAS, J. 1993. Seasonal photosynthetic and respiratory responses of Ruppia cirrhosa to changes in light and temperature. Archiv fur Hydrobiologie, vol. 129, no. 2, p. 221-230.

MOLICA, RJR., OLIVEIRA, EJA., CARVALHO, PVVC., COSTA, ANSF., CUNHA, MCC., MELO, GL. DE and AZEVEDO, SMFO. 2005. Occurence of saxitoxins and an anatoxin-a(s)-like anticholinesterase in a Brazilian drinking water supply. Harmful Algae, vol. 4, no. 4, p. 743-753.

MOLLES, MC. and DAHM, CN. 1990. A perspective on El Niño and La Niña: global implications for stream ecology. Journal North American Benthological Society, vol. 9, no. 1, p. 68-76. http://dx.doi. org/10.2307/1467935

MONTENEGRO, AKA. 2007. Bioecologia da ictiofauna do açude Taperoá II, semi-árido paraibano, Brasil. 
João Pessoa: Universidade Federal da Paraíba. 143 p. [Dissertação de Mestrado].

NEIFF, JJ. and POI DE NEIFF, ASG. 2003. Connectivity processes as a basis for the management of aquatic plants. In THOMAZ, SM. and BINI, LM., eds. Ecologia e Manejo de Macrófitas Aquáticas. Maringá: Eduem. 460 p.

NEWBOLD, JD., O’NEILL, RV., ELWOOD, JW. and VAN WINKLE, W. 1982. Nutrient spiralling in streams: implications for nutrient and invertebrate activity. American Naturalist, vol. 120, p. 628-652. http://dx.doi.org/10.1086/284017

PANOSSO, R., COSTA, IAS., SOUZA, NR., ATTAYDE, JL., CUNHA, SRS. and GOMES, FCF. 2007. Cianobactérias e cianotoxinas em reservatórios do Estado do Rio Grande do Norte e o potencial controle das floraçóes pela tilápia do Nilo (Oreochromis niloticus). Oecologia Brasiliensis, vol. 11, no. 3, p. 433-449. http://dx.doi.org/10.4257/ oeco.2007.1103.12

PEDRO, F., MALTCHIK, L. and BIANCHINI JUNIOR, I. 2006. Hydrologic cycle and dynamics of aquatic macrophytes in two intermittent rivers of the semi-arid region of Brazil. Brazillian Journal Biology, vol. 66, no. 2B, p. 575-585. http://dx.doi. org/10.1590/S1519-69842006000400002

PIMM, SL. 2001. The world according to Pimm: A scientist audits the earth. Chicago: McGrau-Hill. 287 p. http://dx.doi.org/10.1038/35079206

POOLE, GC. 2002. Fluvial landscape ecology: addressing uniqueness within the river discontinuum. Freshwater Biology, vol. 47, p. 641-660. http://dx.doi. org/10.1046/j.1365-2427.2002.00922.x

SCHIAVETTI, A. and CAMARGO, AFM. 2002. Conceitos de bacias hidrográficas: teorias e aplicaçóes. Ilhéus: Editus-Editora da UESC. 293 p.

SMITH, WS. and PETRERE JUNIOR, M. 2001. Caracterização limnológica da bacia de drenagem do Rio Sorocaba, São Paulo, Brasil. Acta Limnologica Brasiliensia, vol. 12, p. 173-186.

SOLOMON, S., QIN, D., MANNING, M., CHEN, Z., MARQUIS, M., AVERYT, KB., TIGNOR, M. and MILLER, HL., eds. 2007. Climate change 2007: the physical science basis. Contribution of working group I to the fourth assessment report of the Intergovernmental Panel on Climate Change. Cambridge: Cambridge University Press. 996 p.

SOUSA, W., ATTAYDE, JL., ROCHA, ES. and ESKINAZI-SANT'ANNA, EM. 2008. The response of zooplankton assemblages to variations in the water quality of four man-made lakes in semiarid northeastern Brazil. Journal of Plankton Research, vol. 30, no. 6, p. 699-708. http://dx.doi. org/10.1093/plankt/fbn032

SOUZA, AHFF. and ABÍLIO, FJP. 2006. Zoobentos de duas lagoas intermitentes da caatinga paraibana e as influências do ciclo hidrológico. Revista de Biologia e Ciências da Terra, vol. 6, no.1, p.146-164.

STANLEY, EH. and FISHER, SG. 1992. Intermittency, disturbance, and stability in stream ecosystems. In ROBARTS, RD. and BOTHWELL, ML., ed. Aquatic Ecosystems in semi-arid regions: implications for resource management N.H.R.I. Saskatoon: Environment Canada. p. 271-280. (Symposium Series, no. 7).

THOMAS, DSG. 2011. Arid Zone Geomorphology: Process, Form and Change in Drylands. WileyBlackwell. 648 p.

THOMAZ, SM., BINI, LM. and PAGIORO, TA. 2003. Macrófitas aquáticas em Itaipu: ecologia e perspectivas para o manejo. In THOMAZ, SM. and BINI, LM., eds. Ecologia e Manejo de Macrófitas Aquáticas. Maringá: Eduem. 460 p.

THORP, JH., THOMS, MC. and DELONG, MD. 2006. The riverine ecosystem synthesis: biocomplexity in river networks across space and time. River Research \& Applications, vol. 22, no. 2, p. 123-147. http://dx.doi.org/10.1002/rra.901

TOOTH, S. 2000. Process, form and change in dryland rivers: a review of recent research. Earth-Science Reviews, vol. 51, no. 1-4, p. 67-107. http://dx.doi. org/10.1016/S0012-8252(00)00014-3

TUNDISI, JG. 2003. Água no século XXI: enfrentando a escassez. São Carlos: Rima 248 p.

TUNDISI, JG. 2008. Recursos hídricos no futuro: problemas e soluçóes. Estudos avançados. São Paulo, vol. 22, no. 63, p. 7-16. http://dx.doi.org/10.1590/ S0103-40142008000200002

TUNDISI, JG. and MATSUMURA-TUNDISI, T. 1995. The Lobo-Broa: ecosystem researc. In TUNDISI, JG., BICUDO, CE. and MATSUMURA-TUNDISI, T., eds. Limnology in Brazil. Rio de Janeiro: Academia Brasileira de Ciências e Sociedade Brasileira de Limnologia. 376 p.

TUNDISI, JG. and SCHIEL, D. 2002. A bacia hidrográfica como laboratório experimental para o ensino de Ciências, Geografia e Educação Ambiental. In SCHIEL, D., MASCARENHAS, S., VALEIRAS, N. and SANTOS, SAM., org. O estudo de bacias hidrográficas, uma estratégia para educação ambiental. São Carlos: Rima. p. 12-17.

VANNOTE, RL., MINSHALL, GW., CUMMINS, KW., SEDELL, JR. and CUSHING, CE. 1980. The river continuum concept. Canadian Journal of Fisheries and Aquatic Sciences, vol. 37, no. 1, p. 130137. http://dx.doi.org/10.1139/f80-017

VASCONCELOS, JF., BARBOSA, JEL., DINIZ, CR. and CEBALLOS, BSO. 2011. Cianobactérias em reservatórios do Estado da Paraíba: ocorrência, toxicidade e fatores reguladores. Boletim da Sociedade Brasileira de Limnologia, vol. 39, no. 2, p. 1-20. 
VIEIRA, ACB. 2007. Dinâmica da comunidade zooplanctônica ao longo de um ciclo hidrológico e a resposta de três espécies de cladóceros (Crustacea, Phyllopoda) a diferentes graus de trofia no açude Taperoá II, semi-árido paraibano. João Pessoa: Universidade Federal da Paraíba. [Dissertação de Mestrado].

WARD, JV. 1989. The four dimensional natures of lotic ecosystems. Journal of the North American Benthological Society, vol. 8, no. 1, p. 2-8. http:// dx.doi.org/10.2307/1467397
WETZEL, RG. 1983. Opening remarks. In WETZEL, RG., ed. Periphyton in freshwater ecosystems. The Hague: Dr. W. Junk Publishers. p. 3-4. (Developments in Hydrobiology, no. 17). http:// dx.doi.org/10.1007/978-94-009-7293-3_2

WILLIAMS, WD. 1999. Conservation of wetlands in drylands: a key global issue. Aquatic Conservation: Marine and Freshwater Ecosystems, vol. 9, p. 517-522. http://dx.doi.org/10.1002/ (SICI) 1099-0755(199911/12)9:6<517::AIDAQC383>3.0.CO;2-C

Received: 30 November 2011 Accepted: 25 June 2012 